\title{
Classification of factors of foreign language phonic competence
}

\author{
Zdena Kralova
}

\section{DOI: 10.18355/XL.2016.09.04.92-99}

\begin{abstract}
Researchers have been investigating the relationship between foreign language learning and its variables and attempting to systematize the factors of influence for about fifty years. However, the classifications differ in their criteria and most of them lack the systematic character. We introduce the classification of factors related to foreign language phonic competence with the emphasis on the language system.
\end{abstract}

Key words: factors - foreign language - pronunciation

\section{INTRODUCTION}

The complex process of language acquisition is an essential part of human cognitive and social development. Communication skills are currently emphasized in foreign language (FL) methodology and pronunciation is one of the primary factors in acoustic-auditive type of communication (Birova - Andrejcakova, 2010). FL pronunciation as a manifestation of non-native phonic system is a specific phenomenon from many points of view. An individual aspect plays much more significant role here than at other language levels. Therefore, the study of FL phonic competence and its variables is rather complicated but very challenging at the same time.

A lot of research studying the variables of FL pronunciation has been conducted in last five decades starting with the classical study of J. J. Asher a R. Garcia (1969). Each person has some potential for FL acquisition that is determined not only by physiological and mental functions but also by the influence of lingual and extralingual environment. N. Segalowitz (1997) assumes three basic criteria of individual differences in a FL competence:

5) flexibility of work with a language system;

6) sensitivity to the conditions of a communication process;

7) coping with the interference between language systems.

There is not any single set of factors definitely representing the FL phonic performance. There exist uncountable determinators of FL competence and uncountable reasons of their variability. The variables can be combined in many different ways and with different resulting effects. Measurement, quantification, diagnostics and prediction of the influence are the necessary preconditions for creating a strategy of FL pronunciation development.

Experience with FL pronunciation teaching/learning and the linguistic analysis of a FL phonic system can be the appropriate starting points in the component analysis of FL phonic competence and performance. Hereby, the difference between two basic terms - language acquisition and language learning - should be reminded as they are still not distinguished consistently in publications and practice. Language acquisition is a natural and spontaneous process of knowledge and skills development in a natural setting, while learning is a conscious and intentional process of knowledge and skills development in an artificially created setting (Stefanik, 2000).

Individual differences in the effectivity of FL acquisition are influenced not only by individual and supra-individual features but also by special FL abilities. "Language talent" undoubtedly consists of many dependent and independent language 
skills and abilities. M. Malikova (1993) considers the following to be the core of FL abilities:

\author{
- $\quad$ phonematic ear; \\ - $\quad$ verbal memory; \\ - $\quad$ grammatical thinking.
}

We focus on the variables potentially affecting the level of phonic competence and performance of a non-native speaker in a FL. The identification and evaluation of such factors is of considerable importance for FL teaching and learning (Mala, 2012). Regarding the specifics of a phonic level within the language system, the relation of theoretical and applied linguistics is unusually direct in this case. A plethora of individual variables enters the process and stating their definite correlation is rather problematic. Both lingual and extralingual variables are part of individual language development and they bring considerable subjectivity and variablity into the research. Nevertheless, they cannot be avoided, just as they cannot be avoided in a real language existence.

\title{
1 FACTORS OF FOREIGN LANGUAGE PHONIC COMPETENCE
}

The studies dealing with the factor analysis of FL phonic competence or performance published so far differ in several dimensions - subjects, objects, methods or research procedures. These differences are problably the reasons of their inconsistent results.

The first review of the relevant research results has been elaborated by R. C. Major (1987) who identified two basic determinants of FL pronunciation - the age of onset and the interlingual interference of a native language. T. Piske, I. R. A. MacKay and J. E. Flege (2001) offered a more detailed analysis of the research and identified the age of onset as a key factor of FL pronunciation quality in accordance with the Critical Period Hypothesis (Lenneberg, 1967). (See also Asher - Garcia, 1969; Oyama, 1976; Tahta - Wood - Loewenthal, 1981; Piper - Cansin, 1988; Thompson, 1991; Flege - Fletcher, 1992; Flege - Munro - MacKay, 1995; Moyer, 1999; Piske MacKay - Flege, 2001; Senel, 2006; Zhang, 2009).

The studies focusing on non-immigrant FL learners call into question the significant influence of the length of stay in a FL country and most of them detected a strong positive correlation (Asher - Garcia, 1969; Seliger - Krashen - Ladefoged, 1975; Oyama, 1979; Tahta - Wood - Loewenthal, 1981; Piper - Cansin, 1988; Flege - Fletcher, 1992; Flege - Munro - MacKay 1995; Flege - Bohn - Jang, 1997; Flege Liu, 2001; Kralova - Krajcovic, 2009).

Social and affective factors are generally considered as strong potential predictors of FL pronunciation quality (Flege, 1987; Kralova - Skorvagova - Ruttkay, 2009; Hu et al., 2012). The impact of attitudinal and motivational factors has not been completely documented yet (partly in Thompson, 1991; Moyer, 1999; Kralova Krajcovic, 2009) though the integrative motivation to achieve an authentic FL pronunciation obtained mostly positive correlation (Purcell - Suter, 1980; Zhang, 2009).

The study of immitation ability, often related to the quality of the ear for music (Suter, 1976; Purcell - Suter, 1980; Thompson, 1991; Hu et al., 2012) and the personality trait of extraversion (Suter, 1976; Kralova - Skorvagova - Ruttkay, 2009) is without any definite conclusions so far. Some authors have been focused on gender differences (e.g. Asher - Garcia, 1969; Flege - Munro - MacKay, 1995; Thompson, 1991) with contradictory findings as well. Female speech production has been often perceived as better than the male speech production (e.g. Tahta - Wood Loewenthal, 1981). However, more studies (e.g. Elliot, 1995; Snow - HoefnagelHohle, 1977; 1979) consider gender differences irrelevant. 
Many authors (for example, Bongaerts - van Summeren - Planken - Schils, 1997; Moyer, 1999; Zhang, 2009) consider the targeted phonetic training significant in learning FL pronunciation. However, the negative proportion has not been exceptional even in this case (Suter, 1976). Factors related to FL teaching and learning like the length of study, an overall FL competence, method of FL learning, context of FL use and structural differences between the primary and secondary language systems have also been studied (Levi - Winters - Pisoni, 2007).

The early research of the factors of FL phonic performance has been oriented at the subject-related variables. R. Ellis (2004) sub-divided the subject-related variables into the learner's abilities, propensities, cognitions and actions. Later on the subjectindependent variables became the focus of attention. However, many research findings have not been consistently replicated yet, thus providing the research validity and reliability and the formulation of convincing conclusions will require further quantitative and qualitative research in a longitudinal design.

\section{CLASSIFICATION OF FACTORS OF FOREIGN LANGUAGE PHONIC COMPETENCE}

There has not been created any unified and compex classification of factors determining FL phonic competence yet. Psychologists (Guilford, 1956) distinguish the so called G-factor (general factor) as a general ability and several S-factors (special factors) specific for various activities. It is to consider the mutual interaction of all factors when studying the language system and the communication act. The authors applied different classification criteria, e. g.:

I) the relation to the subject (Piske - MacKay - Flege, 2001; Zhang, 2009):

1. subject-specific, or subject-dependent factors - inherent to the subject (speaker), experimentally non-manipulatable;

2. complementary factors - non-inherent to the subject, experimentally manipulatable;

II) the relation to the language system (Kamis, 1996; Kralova, 2005):

1. structural (objective, inherent, lingual, language) - resulting from the contact of the language systems;

2. non-structural (subjective, adherent, extralingual, extra-language) resulting from the communication process;

or more specifically (Figure 1):

1. lingual (langue)/internolingual factors - related to the language system, or to the language sign (Sabol, 1993) on the vertical axis:

b) para-lingual factors - temporal phenomena partly related to the language system;

c) extra-lingual factors - permanent phenomena not related to the language system;

2. communication (parole)/externolingual factors - related to the communication on the horizontal axis:

a) intra-communication factors - related to the language communication;

b) para-communication factors - temporal phenomena partly related to the language communication;

c) extra-communication factors - permanent phenomena not related to the language communication. 


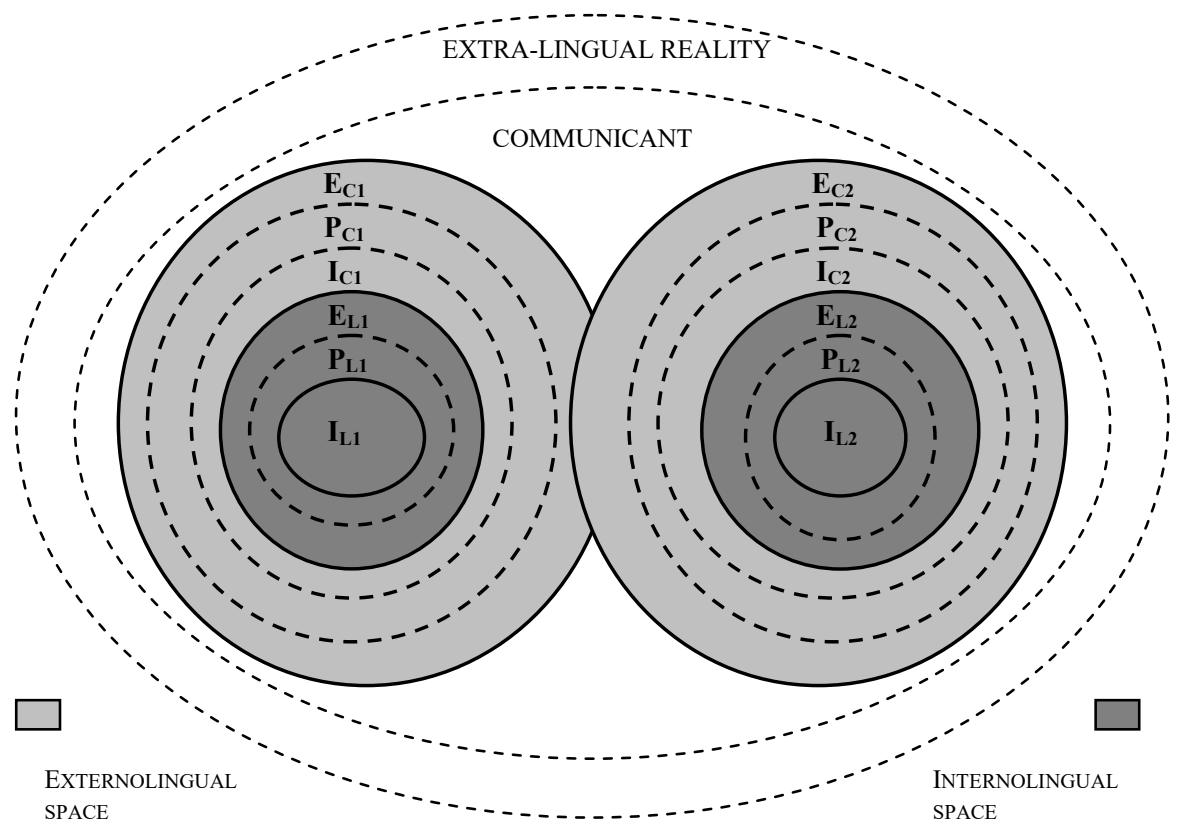

Figure 1 Factors of foreign language competence

$\mathrm{E}_{\mathrm{C} 1}$ - extra-communication factors of the primary language system

$\mathrm{P}_{\mathrm{C} 1}$ - para-communication factors of the primary language system

$\mathrm{I}_{\mathrm{C} 1}$ - intra-communication factors of the primary language system

$\mathrm{E}_{\mathrm{L} 1}$ - extra-lingual factors of the primary language system

$\mathrm{P}_{\mathrm{L} 1}$ - para-lingual factors of the primary language system

$\mathrm{I}_{\mathrm{L} 1}$ - intra-lingual factors of the primary language system

$\mathrm{E}_{\mathrm{C} 2}$ - extra-communication factors of the secondary language system

$\mathrm{P}_{\mathrm{C} 2}$ - para-communication factors of the secondary language system

$\mathrm{I}_{\mathrm{C} 2}$ - intra-communication factors of the secondary language system

$\mathrm{E}_{\mathrm{L} 2}$ - extra-lingual factors of the secondary language system

$\mathrm{P}_{\mathrm{L} 2}$ - para-lingual factors of the secondary language system

$\mathrm{I}_{\mathrm{L} 2}$ - intra-lingual factors of the secondary language system

\subsection{INTERNOLINGUAL FACTORS}

The contact of the phonic systems of a primary (native) and secondary (foreign) language system does not proceed in isolation - intralingually - only in the form of phonic interference, but on the wide background of lingual and extralingual context (Sabol, 1993). The communicant (a multilingual individual) is the centre of a language contact therefore the study of FL competence cannot be limited to the contrastive analysis of two language systems only. It should be understood as the part of individual's language development and respect the relations of the system and its environment - extralingual context of FL competence. 
The interference pressure of a primary phonic system starts in the extralingual space of the secondary phonic system and it can stop anywhere. J. Sabol (1993) considers the intrusion to the intralingual space of a FL to be the completion of the interference process. Specifically, the phenomena and factors of intralingual space are relevant in FL learning/acquisition. The intralingual space is manifested as an integration of FL elements into the language system in general.

Thus the phonologically relevant phenomena manifested mostly as a language interference of the primary language system into the secondary language system can be considered as intralingual (as the oscillation between subjective and objective) according to the theory of language sign.

\subsection{EXTERNOLINGUAL FACTORS}

Everybody is more or less able to learn a foreign language. This ability is affected not only by the biological and psychological characteristics, but also by the lingual and extra-lingual environment. There are countless determinants of FL competence and performance differently affecting each individual.

Herein J. A. Zluktenko (1966) defined the following variables:

the type of language contact:

a) direct, b) mediated;

a) occassional, b) permanent;

1. the form of language contact:

a) natural, b) artificial;

2. the type of bilingualism:

a) individual, b) group;

3. the type of bilingual individual:

a) $\mathrm{Ab}$ (learnt one of the languages as an adult),

b) $\mathrm{AB}$ (learnt both languages as a child),

c) $\mathrm{aB}$ (learnt both languages as a child, but one language has been later suppressed).

Intra-communication factors are the variables related to language communication in the inclusive relation to the intra-, para- and extralingual factors. For example, the competence in other FLs (typologically related/unrelated to the target FL, the sequence of learning other FLs), grammatical (morpho-syntactic) competence in a FL, metaphonetic competence of the FL phonic system, the so-called language sense or language awareness, verbal abilities in the native and foreign languages and the factors related to the process of FL learning - quality, duration, intensity, quality of phonic input, teaching methods and so on.

Para-communication factors, as the temporal phenomena partly related to the language communication, act in a more-less synchronous cross-section and can be sub-classified according to the subject-environment relationship as follows:

a) psycho-para-communication factors (for example, memory for coding the phonic material, emotional relationship to a FL, intelligence, verbal intelligence in native and foreign languages);

b) socio-para-communication factors (for example, the age of FL onset, environment and conditions of FL learning; stay in a FL environment, contact with FL native speakers).

Extra-communication factors, as the permanent phenomena not related to the language communication are highly individual (for example, ear for music, soundimitation ability, type of personality - level of intra-/extraversion and sociability, sensitivity to rejection, self-perception and so on).

The individual and supraindividual extra-lingual factors can be empirically 96

XLinguae Journal, Volume 9 Issue 4, October 2016, ISSN 1337-8384 
and theoretically classified according to several criteria. Nevertheless, they can be considered more-less permeable and interactive. They complement each other and more or less condition the communication effect. Anyway, a more detailed study of their influence and mutual relations is needed.

\section{CONCLUSION}

The research of variables related to the quality of FL phonic competence and performance is not an easy objective and its results are not always satisfactory. One of the biggest methodological pitfalls is a problematic definition of the subject and the methods of partial analyses due to the interactive complexity of characteristics of the final effect - FL pronunciation. FL performance is a moment when the language as a potentionally invariant and general phenomenon joins the currently variant and individual phenomenon - speech. Externolingual dimension of FL phonic competence thus offers much more variability and diffusivity of phenomena because of such a dynamic system of interaction (an individual - an environment). The theoretical and empirical conclusions confirm that FL pronunciation is a complex and complicated phenomenon. It is not always possible to atomize its constituents to learn the whole in details. Nevertheless, it would be alibism to disclaim the suitable generalizations and findings applicable in teaching and learning practice.

\section{Bibliograpic references}

ASHER, J. J. - GARCIA, R. 1969. The optimal age to learn a second language. In: The Modern Language Journal, vol. 53, n. 8, pp. 334-341. ISSN 1540-4781

BIROVA, J. - ANDREJCAKOVA, M. 2010. La competence phonologique en francais chez les locuteurs slovaques: Aspects linguistiques et methodes pedagogiques. Paris: OEP. ISBN 978-2-9537299-0-0

BONGAERTS, T. - Van SUMMEREN, C. - PLANKEN, B. - SCHILS, E. 1997. Age and ultimate attainment in the pronunciation of a foreign language. In: Studies in Second Language Acquisition, vol. 19, n. 4, pp. 447-465. ISSN 0272-2631

ELLIOTT, A. R. 1995. Field independence/dependence, hemispheric specialization, and attitude in relation to pronunciation accuracy in Spanish as a foreign language. In: The Modern Language Journal, vol. 79, n. 3, pp. 356-371. ISSN 1540-4781

ELLIS, R. 2004. Individual Differences in Second Language learning. In: Davies, A., Elder, C. (Eds.): The handbook of applied linguistics [online]. Malden, MA: Blackwell Publishing. 2004, pp. 525-551 Retrieved from:

$<$ http://citeseerx.ist.psu.edu/viewdoc/download?doi=10.1.1.461.5358\&rep=rep1\&type $=$ pdf\#page $=544>$.

FLEGE, J. E. - HILLENBRANDT, J. 1984. Limits on pronunciation accuracy in adult foreign language speech production. In: Journal of the Acoustical Society of America, vol. 76, n. 3, pp. 708-721. ISSN 0001-4966

FLEGE, J. E. 1987. The production of "new" and "similar" phones in a foreign language: Evidence for the effect of equivalence classification. In: Journal of Phonetics, vol. 15, n. 1, pp. 47-65. ISSN 0095-4470

FLEGE, J. E. - FLETCHER, K. L. 1992. Talker and listener effects on degree of perceived foreign accent. In: Journal of the Acoustical Society of America, vol. 91, n. 1, pp. 370-389. ISSN 0001-4966

FLEGE, J. E. - MUNRO, M. J. - MacKAY, I. R. A. 1995. Factors affecting strength of perceived foreign accent in a second language. In: Journal of the Acoustical Society of America, vol. 97, n. 5, pp. 3125-3134. ISSN 0001-4966 
FLEGE, J. E. - BOHN, O. S., JANG, S. 1997. Effects of experience on non-native subject's production and perception of English vowels. In: Journal of Phonetics, vol. 25 , n. 4 , pp. 437-470. ISSN 0095-4470

FLEGE, J. E. - LIU, S. 2001. The effect of experience on adults' acquisition of a second language. In: Studies in Second Language Acquisition, vol. 23, n. 4, pp. 527552. ISSN 0272-2631

GUILFORD, J. P. 1956. The structure of intellect. In: Psychological Bulletin, vol. 53, n. 4, pp. 267-293. ISSN 0033-2909

HU, X. - ACKERMANN, H. - MARTIN, J. - ERB, M. - WINKLER, S. REITERER, S. 2012. Language aptitude for pronunciation in advanced second language (L2) learners: Behavioural predictors and neural substrates. In: Brain and Language, vol. 127, n. 3, pp. 366-376. ISSN 0093-934X

KAMIS, K. 1996. Kodove bariery z hlediska psychologickeho a jejich prekonavani v multikulturnim prostredi. In: Horecky, J. (Ed.): Sociolingvisticke a psycholingvisticke aspekty jazykovej komunikacie, pp. 122-134. ISBN 8089132454

KRAL, A. 1974. Model recoveho mechanizmu. Bratislava: VEDA.

KRALOVA, Z. 2005. Slovensko-anglicka zvukova interferencia. Zilina: EDIS. ISBN 80-89029-85-X

KRALOVA, Z. - KRAJCOVIC, M. 2009. Variance in a Second Language Pronuncation Quality. In: Communications, vol. 11, n. 4, pp. 15-23. ISSN 1335-4205

KRAlOVA, Z. - SKORVAGOVA, E. - RUTTKAY, J. 2009. Some Extralingual Variables of L2 Phonic Competence. In: Communications, vol. 11, n. 2, pp. 70-75. ISSN 1335-4205

LENNEBERG, E. H. 1967. The biological foundations of language. New York: Wiley.

LEVI, S. V. - WINTERS, S. V. - PISONI, D. B. 2007. Speaker-independent factors affecting the perception of foreign accent in a second language. In: Journal of the Acoustical Society of America, vol. 121, n. 4, pp. 2327-2338. ISSN 0001-4966

MAJOR, R. C. 1987. Foreign accent: recent research and theory. In: International Review of Applied Linguistics in Language Teaching, vol. 25, n. 1-4, pp. 185-202. ISSN 1613-4141

MALA, E. 2012. On interference in teaching foreign languages. In: I. Zemberova (Ed.): 15 rokov KLIS PF UKF v Nitre, pp. 88-94. ISBN 978-80-558-0079-0

MALIKOVA, M. 1993. K otazkam cudzojazycnych schopnosti. Recovy sluch. Nitra: Vysoka skola pedagogicka. ISBN 80- 85183-89-7

MOYER, A. 1999. Ultimate attainment in L2 phonology. In: Studies in Second Language Acquisition, vol. 21, n. 1, pp. 81-108. ISSN 0272-2631

OYAMA, S. 1976. A sensitive period for the acquisition of a nonnative phonological system. In: Journal of Psycholinguistic Research, vol. 5, n. 3, pp. 261-283. ISSN 0090-6905

OYAMA, S. 1979. The concept of the sensitive period in developmental studies. In: Merill-Palmer Quarterly, vol. 25, n. 1, pp. 83-102. ISSN 0272-930X

PIPER, T. - CANSIN, D. 1988. Factors influencing the foreign accent. In: The Canadian Modern Language Review, vol. 44, n. 2, pp. 334-342. ISSN 0008-4560

PISKE, T. - MacKAY, I. R. A. - FLEGE, J. E. 2001. Factors affecting degree of foreign accent in an L2: a review. In: Journal of Phonetics, vol. 29, n. 2, pp. 191-215. ISSN 0095-4470

PURCELL, E. T. - SUTER, R. W. 1980. Predictors of pronunciation accuracy: A reexamination. In: Language Learning, vol. 30, n. 2, pp. 271-187. ISSN 1467-9922 RINEY, T. J. - FLEGE, J. E. 1988. Changes over time in global foreign accent and liquid identifiability and accuracy. In: Studies in Second Language Acquisition, vol. 20, n. 2, pp. 213-243. ISSN 0272-2631

98

XLinguae Journal, Volume 9 Issue 4, October 2016, ISSN 1337-8384 
SABOL, J. 1993. K teorii jazykovej interferencie. In: Jazykovedny casopis, vol. 44, n. 1, pp. 87-91. ISSN 0021-5597

SEGALOWITZ, N. - GATBONTON, E. 1977. Studies of the non-fluent bilingual. In: Hornby, P. (Ed.): Bilingualism: Psychological, Sociological, and Educational Implications. New York: Academic Press. ISBN 0-12-356350-X

SELIGER, H. W. - KRASHEN, S. D. - LADEFOGED, P. 1975. Maturational constraints in the acquisition of second language accent. In: Language Sciences, vol. 36, n. 1, pp. 20-22. ISSN 0388-0001

SENEL, M. 2006. Suggestions for Beautifying the Pronunciation of EFL Learners in Turkey. In: Journal of Language and Linguistic Studies, vol. 2, n. 1, pp. 111-125. ISSN 1305-578X

SNOW, C. E. - HOEFNAGEL-HÖHLE, M. 1977. Age differences in the pronunciation of foreign sounds. In: Language and Speech, vol. 20, n. 3, pp. 357-365. ISSN 0023-8309

SNOW, C. E. - HOEFNAGEL-HÖHLE, M. 1979. Individual differences in secondlanguage ability: a factor-analytic study. In: Language and Speech, vol. 22, n. 2, pp. 151-162. ISSN 0023-8309

SUTER, R. W. 1976. Predictors of pronunciation accuracy in second language learning. In: Language Learning, vol. 26, n. 2, pp. 233-253. ISSN 1467-9922

STEFANIK, J. 2000. Hypoteza kritickeho obdobia a slovensky jazyk. In: Jazykovedny casopis, vol. 51, n. 1, pp. 94-113. ISSN 0021-5597

TAHTA, S. - WOOD, M. - LOEWENTHAL, K. 1981. Foreign accents: factors relating to transfer of accent from the first language to a second language. In: Language and Speech, vol. 24, n. 3, pp. 265-272. ISSN 0023-8309

THOMPSON, I. 1991. Foreign accents revisited: the English pronunciation of Russian immigrants. In: Language Learning, vol. 41, n. 2, pp. 177-204. ISSN 14679922

ZHANG, Q. M. 2009. Affecting Factors of Native-Like Pronunciation: A Literature Review [online]. Unpublished dissertation. Chung-Ang University. Retrieved April 7, 2016, from <http://cau.ac.kr/ edusol/see/list/Vol27-2/CAKE027-002-4.pdf $>$

ZLUKTENKO, J. A. 1966. Movni kontakty. Problemy interlingvistyky. Kyjiv: Vydavnyctvo Kyjivskoho universytetu.

Words: 3330

Characters: 23096 (12,83 standard pages)

Zdena Kralova

Faculty of Humanities

Tomas Bata University in Zlin

Mostni 5139

76001 Zlin

Czech Republic

zkralova@fhs.utb.cz 